УДК 656.11:331.461

\title{
CONTRIBUTING FACTORS THAT INFLUENCE ON ROAD TRAFFIC'S RISK
}

\section{O. Kolosok}

National University of Life and Environmental Sciences of Ukraine, Ukraine.

Speciality of article: 275 - transport technologies (by road).

Corresponding author: kolosoc@online.ua.

Article history: Received-April 2020, Accepted-August 2020.

Bibl. 11, fig. 4, tabl. 0 .

Abstract. The level of transport at safety, energy consumption, and impact on the environment in Ukraine do not meet modern requirements. In recent decades, the world has seen a sharp increase in the number of vehicles and an increase in traffic, which leads to a stolen increase in the number of traffic accidents and their negative consequences. There is a whole range of issues that need to be solved, such as high mortality and injury rates as a result of road accidents; a significant part of obsolete vehicles operated by Ukrainian carrier, that is inefficient and harm the environment; the imperfection of the transport safety management system and the absence of a single coordinating body for road safety management, which is the reason for the lack of an integrated system of state road safety management; low level of coordination of actions and institutional capacity of state authorities and local governments to plan and conduct actions in the field of road safety; the imperfection of traffic accident monitoring systems, their statistics, and risk management; ineffective approach in solving the problem of high accident rate and severity of its consequences and creating a scientific basis for activities in the field of road safety; lack of specific measurable goals to increase the level of road safety, the relevant coordinated action plan in this area; unsatisfactory technical condition of a significant number of vehicles and the lack of a system for monitoring the safety of vehicles during their operation; low level of introduction and practical application of the latest technologies and technical means of traffic organization, automated means of control and regulation of traffic; insufficient funding of measures aimed at preventing and reducing the level of accidents, reducing the number of road accidents with real consequences; low level of driver training and lack of effective control over the activities of driving schools; low level of education of the society in the field of road safety, own responsibility and observance of traffic rules, etc.

The car has advantages over other types of vehicles: high mobility, relative ease of operation, the ability to deliver passengers and goods "door to door". It is these advantages of the car that are associated with the negative phenomena that accompany motorization where the lack of traffic safety is in the first place. We can name three important characteristics of modern road transport, which determine the low-level of safety: insufficient provision of road transport with appropriate in their parameters roads; insufficient isolation of traffic flows from other road users; mass driver's profession, which causes a low average level of qualification.

Key words: accident rate, traffic accident, road inspection, traffic-signs, traffic flow.

\section{Introduction}

The growth of the motor-vehicle pool in our country - as a result of the increase in road users leads to an increase in the number of traffic accidents. According to the Strategy for Improving Road Safety in Ukraine till 2020 , the level of deaths and injuries due to the road accidents is the highest in Europe and a level of road safety organization remains extremely low, as experts from the WHO, the World Bank and other international institutions have repeatedly pointed out in their reports.

\section{Formulation of problem}

Over the last six years (2011-2016), about 170.8 thousand road accidents with victims are registered in Ukraine in which 26.7 thousand people died and, 210.4 thousand people were injured. In 2016, the number of road accidents increased by 5.1 per cent and the number of injured people by 6.4 per cent compared to 2015 . Of particular concern is the fact that more than 42.6 per cent of those killed in road accidents in 2016 were pedestrians and cyclists.

\section{Analysis of recent research results}

The work of many domestic and foreign scientists is devoted to the problem of road safety: Babkova V.F., Badalyana A.M., Gavrilova O.A., Dzyuba O.P., Divochkina O.A, Drew D., Derekha Z.D., Eresova VI., Klinkovshteina G.I., Lanovogo O.T., Lobanova E.M., Lukyanova V.V., Polishchuk V.P., Silyanova V.V., 
Fishelson M.S., Halberta S., Chetverukhina B.M., Sheshtokasa V.V., Yudena K. And other [4-11].

The great concern is the fact that 1.4 thousand children under the age of 18 have died on the roads of Ukraine over the last six years, and road accidents in Ukraine are the first most common cause of death among young people aged 15 to 24 and the second most common cause of death of children aged 5 to 14 years [3].

\section{Purpose of research}

The purpose of our study is to identify and analyze the factors influencing the occurrence of road accidents in rural areas.

\section{Results of research}

A large amount of information is required to analyze to identify those that significantly affect the commission of an accident. One of the causes of accidents is insufficient investigation and their timely study. The task requires a large number of observations for the manufacture of soil bran. To conduct research, we have included the necessary information regarding the state of emergency of students who were preparing to defend their bachelor's and master's theses. In the process of analysis, together with students, we worked up the results in (Yagotynsky, Boryspil, KyivSviatoshynsky, Fastiv, Zgurivsky District), Khmelnytsky (Novoushitsky, Starokostiantynivsky districts), Vinnytsia (Illinetsky, Sharrogrodzhivsky).

According to the results of the accident, it established that it was possible to obtain the maximum number of traffic accidents in each village during the year in the range from one to three. However, there are periods when there were no accidents during the year. The main types of accidents are - collision, collision with a pedestrian, collision with an obstacle, collision with a standing vehicle, collision with a cyclist.

The aim of the study has analyzed the areas of the main and residential streets of rural settlements in order to determine the compliance of the characteristics of the parameters of the elements of the cross-sections with state building codes. We concluded that the width of the lanes and their number, meet the normative values, but sidewalks are absent, available only on one side of the street or it is impossible to move, which significantly affects the safety of pedestrians and vehicles (Fig. 1). The outlook of the roadway in the settlements is breaking down (Fig. 1, Fig. 2).

Following the Law of Ukraine "On Road Traffic", there is one uniform order of movement to ensure safety for all its participants in Ukraine. Traffic signs are the most popular and one of the main means of organization and management of traffic and designs to inform its participants about the conditions, modes and directions of traffic [2].

Drivers who are unfamiliar with the road use signs to obtain the necessary information about the road situation. That is why the unreasonableness of the installation of traffic signs or their absence leads to emergency situations. Traffic signs in combination with road markings focus the driver's attention on the road conditions and force them to take the right steps to choose the mode of movement of the vehicle. Pay attention - means to be active about a certain range of objects. Lack of attention is the cause of a significant number of accidents. To conclude we can see that in most areas of streets and roads of rural settlements there are no damaged or selectively traffic signs. Road marking is absent or has not been updated for a significant period, it is invisible (Fig. 3, Fig. 4).

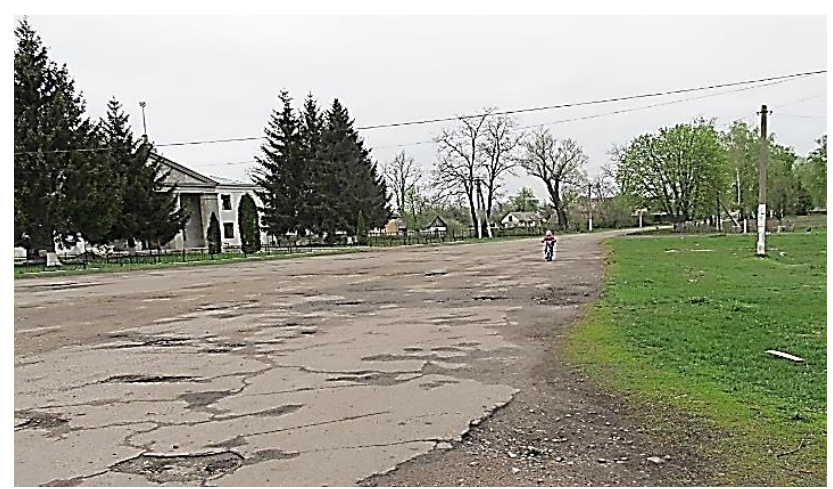

Fig. 1. Section of the road on the str. Ivan Franko in the village Malkivka (no sidewalks, destroyed the road overview).

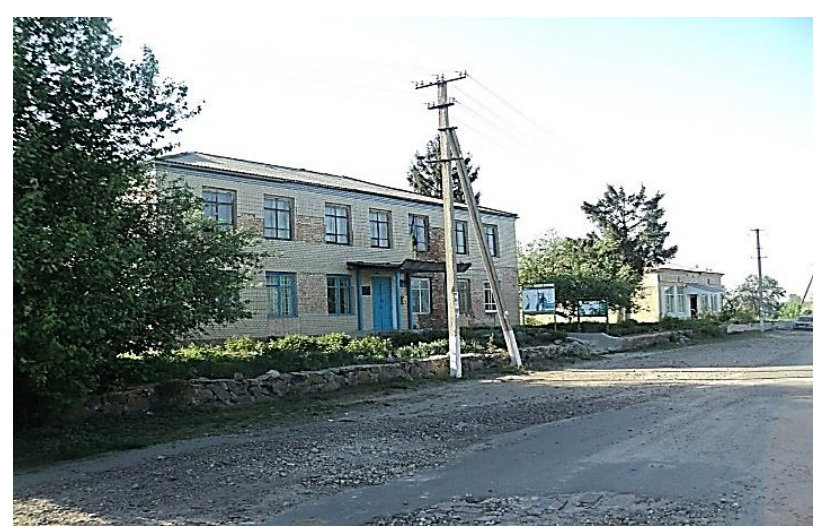

Fig. 2. Section of the road on Skvyrska Street in the village Berezyanka, Ruzhyn district, Zhytomyr region (destroyed the road overview).

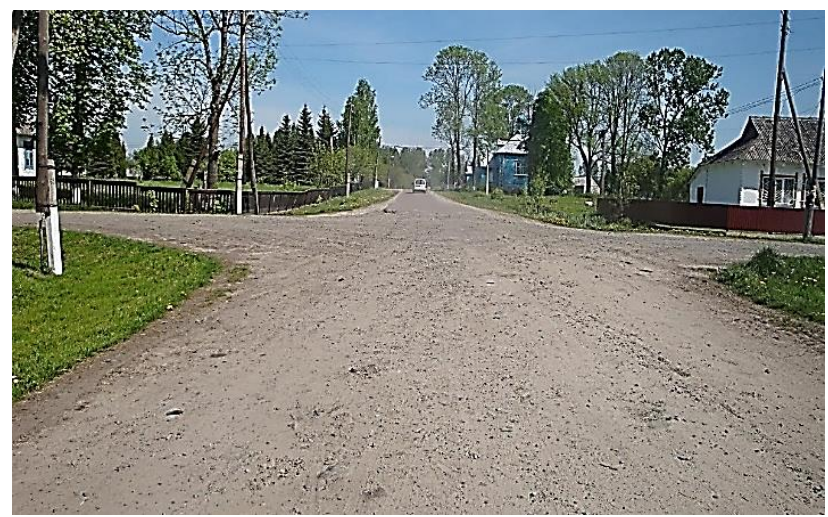

Fig. 3. Intersection in the village. Vyshniv, Volyn region (no priority signs and markings).

In particular, in most villages on the roads there are no: previous signs - "Dangerous turn to the right", "Dangerous turn to the left", "Turn direction", "Road guide", "Children", "Pedestrian crossing", priority signs - "Give the way", "The main road", prohibited - "Maximum speed 
limit", information-indicative - "Pedestrian crossing", "Central bus point", etc. There are no road marking lines, for example, those that determine the order of location on the carriageway of vehicles, mark the boundaries of unregulated pedestrian crossings, identify places where it is necessary to stop the vehicle to give preference to traffic, and so on.

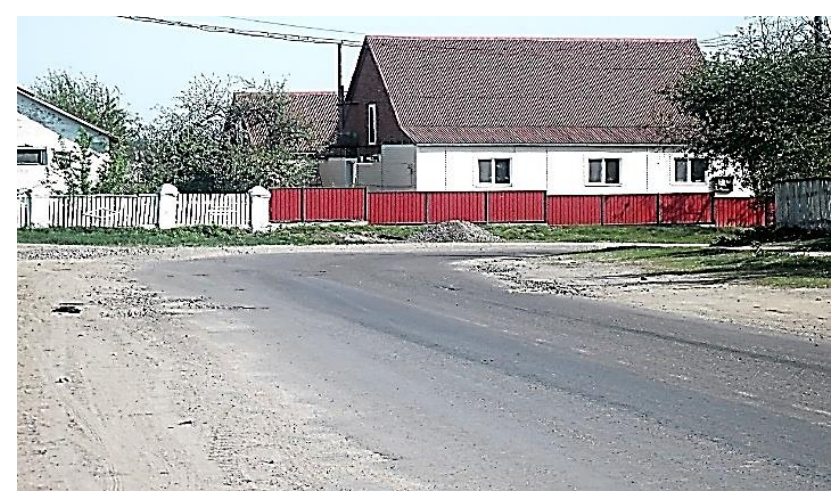

Fig. 4. The section of the main road Kitaygorod, Vinnytsia region (no previous signs 1.1 "Dangerous right turn" and 1.4.1 "Right turn", the road marking is invisible).

The traffic flow dominated by bicycles, motorcycles without wheelchairs and mopeds, cars, trucks with a load capacity of 1 to 8 tons, road trains with a load of up to 12 tons, wheeled tractors with trailers up to 10 tons, buses. Depending on the economic activity within the settlement, self-propelled machines and mechanisms that move from field to field may appear on the roads and streets as part of the traffic flow. Under the influence of trucks, road trains, tractors, self-propelled vehicles, the carriageway has become polluted, and the road overview has destroyed.

The maximum values of traffic intensity are in the range of 11-44 cars per hour. By embracing of agricultural production and the given flow, there are seasonal fluctuations in intensity and low speed, traffic density provoking drivers of motorcycles, cars and trucks to increase the permitted speed in some areas.

As a result of the research, it is established that the current state of road safety in rural settlements is influenced by a number of factors, among which the following can be distinguished: non-compliance of parameters of road cross-section elements with regulatory requirements, unsatisfactory condition of road overview, partial or complete absence of technical means of traffic regulation, lack of artificial lighting of the carriageway or its obsolescence and inefficiency, peculiarities of the traffic flow, weak control by the relevant authorities over the drivers' compliance with traffic rules, as a result of which faulty vehicles appear on the roads or driven by persons who don't have driver's license, or are in a state of intoxication.

The materials of the Organization for Economic Cooperation and Development in recent years highlight the four most significant periods of development of views, approaches and practices of ensuring BDR in the leading countries of the world and, accordingly, four consecutive paradigms. The paradigm is a system of views, approaches, practices in the field of providing BDR, which takes place in certain periods of adaptation of society to peaceful coexistence with a growing number of cars. The concept of successive paradigm shifts to ensure BDR was formed by a number of British and American experts at the turn of the 1960s and 1970s.

The first paradigm of BDR was formed during the initial growth of motorization, ie until about the mid-1920s in the United States and before World War II in Western Europe, Canada, Australia. The key term of the first paradigm is traffic engineering. In the period between the invention of the wheel and the advent of the automobile, the main purpose of road construction was to "free the traveler from the dirt."

The second paradigm prevailed in the United States until the beginning, and in other developed countries until about the mid-1960s In connection with the recognition of the key causes of accidents of individual characteristics of drivers, their inadequate moral qualities and skills, the concept of "three E's" (Enforcement, Education, Engineering coercion, training, design), proposed in the 1920s by the American auto insurance expert Julian Harvey. Accordingly, emphasis was placed on the skills, abilities and psychology of drivers. At the same time, the concept of "3D" (Dangerous, Drunk and Drugged Driving), the essence of which is to identify and stop the facts of dangerous driving, as well as driving under the influence of alcohol and / or drugs.

The era of the third paradigm occurred in the United States in the 1970s. In other highly motorized countries, it lasted from the mid-1960s to the mid-1980s. During that period, the most interesting scientific results were obtained, which allowed to determine the physical nature of the traffic flow, and the corresponding engineering consequences. Some of these results have influenced the ideology of modern traffic control systems.

The fourth paradigm of providing BDR - the period of validity of this paradigm in most countries is still ongoing, although in general today it is possible to determine some formal criteria for its completion. The main reason for the persistence of deaths in road accidents is a purely humanitarian category - "risks of insecurity." In all cases, these are some rules and practices that shape or contribute to further increase the BDR and reduce the "risks of insecurity." A key role in the wide range of measures taken at the local and municipal levels was played by planning decisions aimed at curbing speed and minimizing the risks of pedestrian insecurity. We are talking about streets or other spaces in settlements that are as convenient and safe for pedestrians and at the same time do not provoke intense and high-speed traffic.

The main trends of the fifth paradigm (in those countries to which it directly applies) will be: adaptation to the new transport reality, which is due to the consistent compression of the road space, reducing traffic and road traffic; adaptation to the new ICT-reality, which is due to the total penetration of IT-systems and IT-gadgets in the structure of the car, as well as in the arrangement of roads and urban space; further increase the role and importance of institutional and humanitarian factors in ensuring BDR.

Given the characteristics of the fourth and promising fifth paradigms of BDR, it should be noted that on the roads of our country, especially in rural areas, measures to improve road safety should be consistent with world practices within the fourth paradigm - curbing the speed of vehicles and minimizing the risks of pedestrian insecurity. 


\section{Conclusions}

1. The process of forming road safety is multifaceted and multifactorial. Our analysis has based on a limited amount of information and the need for further research for more comprehensive and objective factors influencing the occurrence of road accidents in rural areas. Materials and conclusions of the research are used in the educational process.

\section{References}

1. Blinkin M. Ya., Reshetova E. M. (2013). Road safety: history of the issue, international experience, basic institutions. Moscow. Publishing house of the Higher School of Economics. 240.

2. Polishchuk V. P., Kunda N. T. (1998). Information support of road users. Kyiv. IZMN. 132.

3. URL: https://zakon.rada.gov.ua/laws/show/4302018-\%D1\%80\#Text.

4. Zagurskiy O., Rogach S., Titova L., Rogovskii I., Pokusa T. (2019). «Green» supply chain as a path to sustainable development. Mechanisms of stimulation of socioeconomic development of regions in conditions of transformation. Monograph. Opole: The Academy of Management and Administration in Opole. 199-213.

5. Bektas T., Laporte G. (2011). The pollutionrouting problem. Transportation Research B: Methodological. 45(8). 1232-1250.

6. Zagurskiy O., Ohiienko M., Pokusa T., Zagurska S., Pokusa F., Titova L., Rogovskii I. (2020). Study of efficiency of transport processes of supply chains management under uncertainty. Monograph. Opole: The Academy of Management and Administration in Opole. 162.

7. Rogovskii I., Titova L., Novitskii A., Rebenko V. (2019). Research of vibroacoustic diagnostics of fuel system of engines of combine harvesters. Engineering for Rural Development. 18. 291-298.

8. Christof Dr., Ehrhart E. (2012). Delivering Tomorrow: Towards Sustainable Logistics. Bonn, Germany: Deutsche Post AG. Retrieved from http://www.delivering-tomorrow.com.

9. Dekker R., Bloemhof J., Mallidis I. (2012). Operations Research for green logistics - An overview of aspects, issues, contributions and challenges. European Journal of Operational Research. 219. 671-679.

10. Zapadlovsky Oleksandr, Rogovskii Ivan. (2018). Determination of speed of automotive vehicle on basis of laws of conservation of energy and momentum. TEKA. An International Quarterly Journal on Motorization, Vehicle Operation, Energy Efficiency and Mechanical Engineering. Lublin-Rzeszów. 18(2). 97-103.

11. Grubrin O. M., Rogovskii I. L. (2018). Accuracy of converting videoendoscopy combine harvester using generalized mathematical model. Scientific Herald of National University of Life and Environmental Science of Ukraine. Series: Technique and energy of APK. Kyiv. 298. 149-156. DOI: 10.31548/machenergy.2018.04.149-156.

\section{Список літератури}

1. Блинкин М. Я., Решетова Е. М. Безопасность дорожного движения: история вопроса, международный опыт, базовые институции. Москва. Издательский дом Высшей школы экономики, 2013. 240 с.

2. Полішук В. П., Кунда Н. Т. Інформаційне забезпечення учасників дорожнього руху: навчальний посібник. Київ. ІЗМН, 1998. 132 с.

3. URL: https://zakon.rada.gov.ua/laws/show/4302018-\%D1\%80\#Text.

4. Zagurskiy O., Rogach S., Titova L., Rogovskii I., Pokusa T. "Green» supply chain as a path to sustainable development. Mechanisms of stimulation of socio-economic development of regions in conditions of transformation. Monograph. Opole: The Academy of Management and Administration in Opole. 2019. P. 199-213.

5. Bektas T., Laporte G. The pollution-routing problem. Transportation Research B: Methodological. 2011. Vol. 45(8). P. 1232-1250.

6. Zagurskiy O., Ohiienko M., Pokusa T., Zagurska S., Pokusa F., Titova L., Rogovskii I. Study of efficiency of transport processes of supply chains management under uncertainty. Monograph. Opole: The Academy of Management and Administration in Opole. 2020. 162 p.

7. Rogovskii I., Titova L., Novitskii A., Rebenko V. Research of vibroacoustic diagnostics of fuel system of engines of combine harvesters. Engineering for Rural Development. 2019. Vol. 18. P. 291-298.

8. Christof Dr., Ehrhart E. Delivering Tomorrow: Towards Sustainable Logistics. Bonn, Germany: Deutsche Post AG. 2012. Retrieved from http://www.delivering-tomorrow.com.

9. Dekker R., Bloemhof J., Mallidis I. Operations Research for green logistics - An overview of aspects, issues, contributions and challenges. European Journal of Operational Research. 2012. Vol. 219. P. 671-679.

10. Zapadlovsky Oleksandr, Rogovskii Ivan. Determination of speed of automotive vehicle on basis of laws of conservation of energy and momentum. TEKA. An International Quarterly Journal on Motorization, Vehicle Operation, Energy Efficiency and Mechanical Engineering. 2018. Lublin-Rzeszów. Vol. 18. No 2. P. 97-103.

11. Grubrin O. M., Rogovskii I. L Accuracy of converting videoendoscopy combine harvester using generalized mathematical model. Scientific Herald of National University of Life and Environmental Science of Ukraine. Series: Technique and energy of APK. Kyiv. Vol. 298. P. 149-156. DOI: 10.31548/machenergy.2018.04.149-156.

\section{ФАКТОРИ, ЩО ВПЛИВАЮТЬ НА ВИНИКНЕННЯ РИЗИКУ У ДОРОЖНЬОМУ РУСІ \\ I. О. Колосок}

Анотація. Рівень безпеки перевезень, обсяг споживання енергії та вплив на навколишнє природне середовище в Україні не відповідають сучасним вимогам. Протягом останніх десятиліть у світі спостерігається стрімке збільшення кількості транспортних засобів та підвищення інтенсивності руху, що призводить до збільшення кількості транспортних подій та їх негативних наслідків. Існує цілий комплекс проблем, 
що потребує розв'язання, а саме: високий рівень смертності та травматизму в результаті дорожньо-транспортних пригод; значна частина транспортних засобів, що експлуатуються українськими перевізниками, $\epsilon$ застарілими, неефективними та справляють значний негативний вплив на навколишнє природне середовище; недосконалість системи управління безпекою на транспорті та відсутність єдиного координаційного органу управління безпекою дорожнього руху, що є причиною відсутності цілісної системи державного управління безпекою дорожнього руху; низький рівень координації дій та інституційної спроможності органів державної влади та органів місцевого самоврядування щодо планування і проведення дій у сфері безпеки дорожнього руху; недосконалість систем моніторингу дорожньо-транспортних пригод, їх статистики та управління ризиками; неефективний підхід до розв'язання проблеми високого рівня аварійності та тяжкості її наслідків і створення наукового підгрунтя діяльності у сфері безпеки дорожнього руху; відсутність конкретних вимірних цілей з підвищення рівня безпеки дорожнього руху, відповідного скоординованого плану дій у зазначеній сфері; незадовільний технічний стан значної кількості транспортних засобів та відсутність системи здійснення контролю за безпечністю транспортних засобів під час їх експлуатації; низький рівень запровадження та практичного застосування новітніх технологій і технічних засобів організації дорожнього руху, автоматизованих засобів контролю та регулювання дорожнього руху; недостатнє фінансування заходів, спрямованих на запобігання та зниження рівня аварійності, зменшення кількості дорожньо-транспортних пригод з тяжкими наслідками; низький рівень підготовки водіїв та відсутність ефективного контролю за діяльністю автошкіл; низький рівень виховання суспільства у сфері безпеки дорожнього руху, власної відповідальності та дотримання правил дорожнього руху тощо.

Автомобіль володіє перевагами перед іншими видами транспортних засобів: високою мобільністю, відносною простотою керування, здатністю доставляти пасажирів та вантажі “від дверей до дверей”. Саме 3 цими перевагами автомобіля пов'язані наведені негативні явища, що супроводжують автомобілізацію, і в першу чергу недостатній рівень безпеки руху. Можна назвати три важливих характерних риси сучасних автомобільних перевезень, що визначають низький рівень безпеки: недостатня забезпеченість автомобільного транспорту відповідними за своїми параметрами дорогами; недостатня ізоляція транспортних потоків від інших учасників дорожнього руху; масовість професії водія, яка обумовлює невисокий середній рівень кваліфікації.

Ключові слова: аварійність, дорожньо-транспортна пригода, дорожній одяг, дорожні знаки, транспортний потік.
ФАКТОРЫ, ВЛИЯЮЩИЕ НА ВОЗНИКНОВЕНИЕ РИСКА В ДОРОЖНОМ ДВИЖЕНИИ

\section{И. А. Колосок}

Аннотация. Уровень безопасности перевозок, объем потребления энергии и влияние на окружающую среду в Украине не соответствуют современным требованиям. В течение последних десятилетий в мире наблюдается стремительное увеличение количества транспортных средств и повышения интенсивности движения, что приводит к увеличению количества транспортных происшествий и их негативных последствий. Существует целый комплекс проблем, который требует решения, а именно: высокий уровень смертности и травматизма в результате дорожно-транспортных происшествий; значительная часть транспортных средств, эксплуатируемых украинскими перевозочиками, являются устаревшими, неэффективными и оказывают значительное негативное воздействие на окружающую среду; несовершенство системы управления безопасностью на транспорте и отсутствие единого координацийного органа управления безопасностью дорожного движения, является причиной отсутствия целостной системы государственного управления безопасностью дорожного движения; низкий уровень координации действий и институциональной способности органов государственной власти и органов местного самоуправления по планированию и проведению действий в сфере безопасности дорожного движения; несовершенство систем мониторинга дорожно-транспортных происшествий, их статистики и управления рисками; неэффективен подход к решению проблемы высокого уровня аварийности и тяжести ее последствий и создание научной базы деятельности в сфере безопасности дорожного движения; отсутствие конкретных измеримых целей по повышению уровня безопасности дорожного движения, соответствующего скоо-рдинованого плана действий в указанной сфере; неудовлетворительное техническое состояние значительного количества транспортных средств и отсутствие системы осуществления контроля за безопасностью транспортных средств во время их эксплуатации; низкий уровень внедрения и практического применения новейших технологий и технических средств организации дорожного движения, автоматизированных средств контроля и регулирования дорожного движения; недостаточное финансирование мероприятий, направленных на предупреждение и снижение уровня аварийности, уменьшение количества дорожно-транспортных происшествий с тяжелыми последствиями; низкий уровень подготовки водителей и отсутствие эффективного контроля за деятельностью автошкол; низкий уровень воспитания общества в сфере безопасности дорожного движения, собственной ответственности в соблюнии правил дорожного движения и тому подобное.

Автомобиль обладает преимуществами перед другими видамы транспортных средств: высокой мобильностью, простотой управления, способностью доставлять пассажиров и грузы "от двери до двери". Именно с этими преимуществами автомобиля связаны негативные явления, сопровождающие автомобилизации, и в первую очередь недостаточный уровень безопасности движения. Можно выделить три важных характерные 
черты современных автомобильных перевозок, которые определяют низкий уровень безопасности: недостаточная обеспеченность автомобильного транспорта соответствующими по своим параметрам дорогам; недостаточная изоляция транспортных потоков от других участников дорожного движения; массовость профессии водителя, которая обусловливает невысокий средний уровень квалификации.

Ключевые слова: аварийность, дорожно-транспортное происшествие, дорожная одежда, дорожные знаки, транспортный поток.

I. О. Колосок ORCID 0000-0001-9543-8782. 